\title{
Study of Textural and Instrumental Colour Characteristics of Khoa Developed Using Milk Solids
}

\author{
Vaquil", P.K. Bhardwaj, Rekha Devi, Surender Kumar and S.S. Ahlawat
}

Department of Livestock Products Technology, College of Veterinary Sciences, Lala Lajpat Rai University of Veterinary \& Animal Sciences, Hisar, Haryana, India

*Corresponding author

\section{A B S T R A C T}

\begin{tabular}{|l|}
\hline Ke y w o r d s \\
$\begin{array}{l}\text { Milk solids, } \\
\text { Homogenization, } \\
\text { Textural properties and } \\
\text { instrumental colour }\end{array}$ \\
\hline Article Info \\
\hline $\begin{array}{l}\text { Accepted: } \\
\text { 20 July 2018 } \\
\text { Available Online: } \\
\text { 10 August } 2018\end{array}$ \\
\hline
\end{tabular}

\section{Introduction}

Khoa, a popular Indian indigenous milk product, prepared by heat desiccation of whole milk in an open pan to a semi-solid consistency to $68-70 \%$ total solids content. It is usually used for direct consumption or the base material for several Indian dairy products like gulabjamun, pantooa, peda, etc. Khoa is one of the most important product in India, Nepal, Bangladesh and Pakistan (Choudhary et al., 2015).

The textural characteristics of a dairy product is always influenced by its composition, type and quality of raw materials used and manufacturing practices/parameters followed during preparation. Texture of khoa also plays an important role in its suitability for the production of sweets and out of three different types of khoa (dhap, danedar and pindi), pindi khoa (26-34\% moisture) has a smooth-grained texture and a firm body and is extensively used as an ingredient (Rajorhia and Srinivasana, 1979). Textural properties, composition and microstructure are interrelated to each other. Hardness, gumminess and chewiness are negatively correlated with moisture and fat content, but positively with protein, lactose, added carbohydrates, ash and calcium content (Adhikari et al., 1994). As a result of complex interactions occurring among the individual milk components like casein, whey protein, 
lactose and fat globules during the production of milk products, results in changes in texture (De, 2004). Therefore, milk solids were utilized for development of khoa and to study textural and instrumental colour characteristics and compare these properties with full cream buffalo milk (6\% fat) khoa.

\section{Materials and Methods}

\section{Procurement of raw materials}

Ghee, cream (50\% fat) and full cream buffalo milk (6\% fat) were procured from experimental dairy plant, Department of LPT, LUVAS, Hisar. Skim milk powder and whey protein concentrate were procured from local market of Hisar.

\section{Preparation of khoa using milk solids}

\section{Standardization}

Khoa was standardized for fat by Pearson's square method as described by De (2004). Standardization was done to meet legal standard of fat $(20 \%$ fat on fresh basis and $30 \%$ fat on dry basis).

\section{Preparation of mixture}

Two type of khoa samples were prepared by using milk solids. First type by using skim milk powder and ghee and second type by using skim milk powder and cream (50\% fat). For first type khoa, 680g SMP $(13.6 \%)+300 \mathrm{~g}$ ghee $(6 \%)+20 \mathrm{~g}(0.4 \%)$ whey protein concentrate were mixed and add hot water $(80 \%)$ to make total weight $5 \mathrm{~kg}$. Similarly for second type khoa, 500g SMP $(10 \%)+480 \mathrm{~g}$ cream $(9.6 \%)$ were mixed and add hot water $(80.4 \%)$ to make total weight $5 \mathrm{~kg}$. After proper mixing filtration was done followed by preheating up to $65^{\circ} \mathrm{C}$. Then homogenization (single stage and double stage) and desiccation in semiautomatic machine (gas operated and steam operated). So depending on homogenization stage and desiccation four treatments was prepared from each mixture. Selection of final products was done on basis of sensory score. Control khoa sample was prepared using full cream buffalo milk $(6 \%$ fat) in gas operated semi-automatic machine.

\section{Analysis}

\section{Texture profile analysis}

The texture profile of khoa samples were determined Bourne, (1978) method using texture analyzer fitted with $25 \mathrm{~kg}$ load cell using cylindrical P75 probe. The samples were cut into $1 \mathrm{~cm} 3$ sizes and subjected to texture analyzer with pre-test and post-test speed of 2 $\mathrm{mm} / \mathrm{s}$ and test speed of $1 \mathrm{~mm} / \mathrm{s}$ with compression of $50 \%$ of distance with single TPA (texture profile analysis). From the resulting force-time graph, obtained with force experienced by probe on $\mathrm{Y}$-axis and time on $\mathrm{X}$-axis various textural characteristics such as hardness, cohesiveness, adhesiveness, springiness, gumminess and chewiness were calculated using the Texture Expert Exceed software supplied by the manufacturer along with the instrument. The firmness of khoa sample was estimated as the height of positive peak force up to rupture point. A minimum of three replicates per sample was run.

\section{Colour estimation}

Colour measurements were conducted using chroma meter (Hunter Associates Laboratory, Inc., Reston VA, USA) colour measurement system equipped with dual beam xenon flash lamp and universal software. The instrument was calibrated prior to sample measurements with standard black, white and green tile as prescribed by the supplier. The results were represented by the $L^{*}, a^{*}, b^{*}$ notation. It is a $3 \mathrm{D}$ colour presentation method in which $\mathrm{L}^{*}$ is the lightness index of colour and equals 0 for 
black and 100 for white. a* value is redness and greenness index the amount of red ( 0 to $60)$ or green ( 0 to -60$)$ while $b^{*}$ value is the yellowness ( 0 to 60$)$ or blueness $(0$ to -60$)$ index

\section{Statistical analysis}

The whole set of experiment was conducted three times for consistency of results. Results were statistical analysed for analysis of variance (ANOVA) using SPSS 16 for Windows as per standard methods (Snedecor and Cochran, 1994). Duncan's multiple range test at 5\% significance level was applied to find out significant differences in mean and results were expressed as mean \pm standard error.

\section{Results and Discussion}

Significantly higher value of hardness in khoa prepared from skim milk powder and ghee might be due to higher total solids. Our findings were accordance with Gupta et al., (1990) and Suresh and Jha (1994) who also reported the increased hardness of khoa highly correlated with the total solids. Adhikari et al., (1994) also reported negative correlation between moisture and instron hardness of khoa. Deep (2009) reported a range of hardness from 10.23 to $49.95 \mathrm{~N}$. Our finding also lies within this range but contraindicated to Choudhary et al., (2016), they reported lower value of hardness in buffalo milk khoa. Springiness values of all products were found significantly differ to each other and highest value was reported in skim milk powder and cream khoa followed by skim milk powder and ghee khoa then control in decreasing order. These finding were according Choudhary et al., (2016) and Deep (2009). The cohesiveness value of khoa prepared from skim milk powder and cream have significant higher value than the control and skim milk powder and ghee khoa. This difference in cohesiveness value might be due to moisture difference in khoa samples. Adhikari et al., (1994) also reported negative correlation between moisture and cohesiveness of khoa. Our cohesiveness values of khoa were in agreement with Deep (2009) reports.

Gumminess value of skim milk powder and ghee khoa sample was found significantly higher than control. This higher value of skim milk powder and ghee khoa might be due to higher total solids. Gupta et al., (1990) and Adhikari et al., (1994) also reported that an increase in total solids resulted in increase in instron gumminess in khoa. Our results were according to Deep (2009), but Choudhary et al., (2016) observed higher value of gumminess in buffalo milk khoa. Since gumminess is a secondary parameter derived from hardness and cohesiveness, hence a slight change in these two textural parameters also affected it (Table 1).

Table.1 Textural properties of khoa (Mean \pm S.E., $n=6)$

\begin{tabular}{|c|c|c|c|}
\hline Parameter & Control & $\mathrm{T} 1$ & $\mathrm{~T} 2$ \\
\hline Hardness $(\mathbf{N})$ & $24.76 \pm 0.72^{\mathrm{B}}$ & $20.74 \pm 0.46^{\mathrm{C}}$ & $28.16 \pm 0.66^{\mathrm{A}}$ \\
\hline Springiness & $0.44 \pm 0.01^{\mathrm{C}}$ & $0.63 \pm 0.05^{\mathrm{A}}$ & $0.54 \pm 0.05^{\mathrm{B}}$ \\
\hline Cohesiveness & $0.23 \pm 0.01^{\mathrm{B}}$ & $0.29 \pm 0.01^{\mathrm{A}}$ & $0.24 \pm 0.01^{\mathrm{B}}$ \\
\hline Gumminess $(\mathbf{N})$ & $5.74 \pm 0.18^{\mathrm{B}}$ & $6.04 \pm 0.37^{\mathrm{AB}}$ & $6.72 \pm 0.23^{\mathrm{A}}$ \\
\hline Chewiness & $2.53 \pm 0.07^{\mathrm{B}}$ & $3.85 \pm 0.33^{\mathrm{A}}$ & $3.64 \pm 0.24^{\mathrm{A}}$ \\
\hline Resilience & $0.07 \pm 0.001^{\mathrm{B}}$ & $0.10 \pm 0.011^{\mathrm{A}}$ & $0.08 \pm 0.003^{\mathrm{AB}}$ \\
\hline
\end{tabular}

Means with different capital letter superscripts in a row within differ significantly $(\mathrm{P} \leq 0.05) . \mathrm{C}=$ khoa from full cream milk, T1= khoa sample from SMP and cream, T2= khoa sample from SMP, ghee and 0.4\% WPC. 
Table.2 Instrumental colour score of khoa (Mean \pm S.E., $n=6)$

\begin{tabular}{|c|c|c|c|}
\hline Sample & $L^{*}$ value (Lightness) & $a^{*}$ value (Redness) & $b *$ value(Yellowness) \\
\hline Control & $65.13 \pm 0.69^{\mathrm{C}}$ & $2.59 \pm 0.10^{\mathrm{A}}$ & $16.40 \pm 0.32^{\mathrm{B}}$ \\
\hline T1 & $75.87 \pm 0.43^{\mathrm{A}}$ & $1.42 \pm 0.04^{\mathrm{C}}$ & $14.65 \pm 0.14^{\mathrm{C}}$ \\
\hline T2 & $61.02 \pm 0.46^{\mathrm{B}}$ & $2.06 \pm 0.09^{\mathrm{B}}$ & $17.37 \pm 0.32^{\mathrm{A}}$ \\
\hline
\end{tabular}

Means with different capital letter superscripts in a column within differ significantly $(\mathrm{P} \leq 0.05)$. Control= khoa from full cream milk, T1=khoa sample from SMP and cream, T2= khoa sample from SMP, ghee and $0.4 \%$ WPC.

Chewiness values of both khoa samples (T1 and T2) prepared using milk solids were reported significantly higher than control. This may be due to fact that chewiness is directly proportional to hardness so it shows nearly same trends as hardness does. Gupta $e t$ al., (1990) and Adhikari et al., (1994) also reported an increase in total solids resulted in increase in instron chewiness in khoa.

Since chewiness is a secondary parameter derived from hardness, cohesiveness and springiness, hence a slight change in these textural parameters also affected it.

In control sample $L^{*} b^{*}$ and $a^{*}$ values were reported 65.13, 2.59 and 16.40, respectively (Table 2). But Choudhary et al., (2016) observed slightly higher value of $L^{*}$ (72.47), $b^{*}$ (3.53) and $a^{*}$ (21.89).

This might be due to steam desiccation of milk. Lightness value of khoa prepared from skim milk powder and ghee with incorporation of whey protein concentrate was found significantly lower than other sample. This might be due to the addition of protein which results in more maillard reaction and formations of browning compounds result in development of browning colour (Morales and Boekel, 1998).

So it can be concluded from the present study that khoa prepared with milk solids $(13.6 \%$ SPM+ $6 \%$ ghee+ $0.4 \%$ WPC and $10 \%$ SMP + $9.6 \%$ cream) can be prepared with improved textural profile characteristics.

\section{References}

Adhikari A.K., Mathur O.N. and Patil G.R. 1994. Interrelationship among instron textural parameters, Composition and Microstructure of khoa and gulabjamun made from buffalo milk. J. Food Sci. Technol., 31(4): 279-284.

Bourne M.C. 1978. Texture profile analysis. Food Technol., 32: 62-66.

Choudhary S. 2015. Studies on heat induced changes in khoa as influenced by quality of milk. Ph.D thesis submitted to NDRI, Karnal, Haryana.

Choudhary S., Arora S., Kumari A., Narwal V. and Sharma V. 2016. Impact of developed acidity in milk and subsequent neutralization on changes in physico-chemical properties and oxidative stability of khoa. Indian $J$. Dairy Sci., 69(6): 665-675.

De, S. 2004. Outlines of dairy technology, 19th edition, Oxford publishing Company, New Delhi.

Deep A. 2009. Feasibility study on manufacture of danedar khoa using three stage scraped surface heat exchanger. M. Tech. thesis submitted to the NDRI, Karnal, Haryana.

Gupta S.K., Patil G.R., Patel A.A., Garg F.C. and Rajorhia G.S. 1990. Instron texture profile parameters of khoa as influenced by composition. J. Food Sci. Techol., 27(4): 209-213.

Morales F.J. and Boekel M.J. 1998. A study on advanced Maillard reaction in heated 
casein/sugar solutions: color formation. Inter Dairy J., 8: 907-915.

Rajorhia G.S. and Srinivasan M.R. 1979. Technology of khoa - a review. Indian J. Dairy Sci., 32(3): 209-216.

Snedecor G.W. and Cochran W.G. 1994. Statistical method, $8^{\text {th }}$ edition, Oxford and IBAS publishing Company Calcutta. 172-196.

Suresh I. and Jha Y.K. 1994. Sensory, biochemical and microbiological qualities of kalakand. J. Food Sci. Technol., 31: 330-332.

\section{How to cite this article:}

Vaquil, P.K. Bhardwaj, Rekha Devi, Surender Kumar and Ahlawat, S.S. 2018. Study of Textural and Instrumental Colour Characteristics of Khoa Developed Using Milk Solids. Int.J.Curr.Microbiol.App.Sci. 7(08): 3819-3823. doi: https://doi.org/10.20546/ijcmas.2018.708.390 